\title{
Reproductive assurance in three Neotropical species of Podostemaceae: strategies of self-pollination and the first report of apomixis ${ }^{1}$
}

\author{
- Inara Carolina da Silva-Batista ${ }^{2,4},{ }^{\circ}$ Cristiana Koschnitzke $^{3}$ and ${ }^{\circ}$ Claudia Petean Bove $^{3}$
}

Received: 14 March 2019; accepted: 11 December 2019

How to cite: Silva-Batista, I.C., Koschnitzke, C. \& Bove, C.P. Reproductive assurance in three Neotropical especies of Podostemaceae: strategies of self-pollination and the first report of apomixis. Hoehnea 47: e212019. http://dx.doi. org/10.1590/2236-8906-21/2019.

ABSTRACT - (Reproductive assurance in three Neotropical species of Podostemaceae: strategies of self-pollination and the first report of apomixis). The aspects of reproductive assurance of the Lophogyne lacunosa (Gardner) C.P.Bove \& C.T.Philbrick, Podostemum weddellianum (Tul.) C.T. Philbrick \& Novelo, and Tristicha trifaria (Bory ex Willd.) Spreng. were investigated and, the mechanisms correlated to the flower morphology and floral biology. The mating system of $\mathrm{L}$. lacunosa was also described, as well as the first report of apomixis in Podostemaceae. The reproductive assurance strategies used by L. lacunosa were autonomous competitive self-pollination, wind pollination, and apomixis. This species has floral attributes that ensure the dispersion of pollen by wind and its capture by the stigmas. Podostemum weddellianum and Tristicha trifaria presented autonomous competitive self-pollination before and during anthesis, respectively; both lack floral attributes for wind pollination. Considering that these species can be found in the same running water environment and that they are not phylogenetically close related, it was concluded that the different reproductive strategies are related to their evolutionary lineages.

Keywords: aquatic plants, asexual reproduction, cleistogamy, parthenocarpy, Podostemoideae, Tristichoideae

RESUMO - (Segurança reprodutiva em três espécies Neotropicais de Podostemaceae: estratégias de autopolinização e o primeiro relato de apomixia para a família). Foram investigados os aspectos relacionados à garantia reprodutiva de Lophogyne lacunosa (Gardner) C.P.Bove \& C.T.Philbrick, Podostemum weddellianum (Tul.) C.T. Philbrick \& Novelo e Tristicha trifaria (Bory ex Willd.) Spreng., relacionando esses mecanismos com a morfologia das flores e biologia floral. São apresentados o sistema reprodutivo de Lophogyne lacunosa e o primeiro relato de apomixia para família. As estratégias de garantia reprodutiva utilizadas por L. lacunosa foram autopolinização durante antese, polinização pelo vento e apomixia. Essa espécie possui atributos florais que garantem a dispersão do pólen pelo vento e sua captura pelos estigmas. Podostemum weddellianum e Tristicha trifaria apresentaram autopolinização autônoma antes e durante a antese; os atributos florais para polinização pelo vento estavam ausentes em ambas. Levando em conta que essas espécies vivem no mesmo ambiente de águas correntes e não estão filogeneticamente próximas, concluímos que suas diferentes estratégias estão relacionadas com suas próprias linhagens evolutivas.

Palavras-chave: cleistogamia, partenocarpia, plantas aquáticas, Podostemoideae, reprodução assexuada, Tristichoideae

\section{Introduction}

Pollination is a crucial requirement for seed production and depends on several features, for example, the stigma receptivity period, pollen viability, number of pollen grains deposited on the stigma, favorable environment for pollination, and presence or absence of pollinators (Shivanna 2015).
In environments that are unfavorable or stressful for crossing between individuals, angiosperms may have strategies to ensure seed production (reproductive assurance), such as autonomous self-pollination (Eckert et al. 2002, Shivanna 2015) or apomixis (Eckert et al. 2002). The latter strategy is an asexual mode of reproduction that produces viable seeds

1. Parte da Dissertação de Mestrado da primeira Autora

2. Universidade do Estado do Rio de Janeiro, Faculdade de Educação - Curso de Pedagogia/ Edu cação a Distância, Rua São Francisco Xavier, 524, Maracanã, 20550-900, Rio de Janeiro, RJ, Brasil

3. Universidade Federal do Rio de Janeiro, Museu Nacional, Departamento de Botânica, Quinta da Boa Vista s.n., São Cristóvão, 20940040 Rio de Janeiro, RJ, Brasil

4. Corresponding author: inaracarolina@hotmail.com 
without fertilization, with the progeny having a genotype identical to the parent plant (Koltunow \& Grossniklaus 2003).

Particularly unfavorable environments for pollinators are waterfalls and rapids (Sobral-Leite et al. 2011), habitats of Podostemaceae species (e.g. Philbrick et al. 2010). This is the largest family of exclusively aquatic angiosperms, containing about 280 species, which have a rheophilic habit and flower during the dry season when plants are exposed to the air (e.g. Philbrick et al. 2010). Podostemaceae has three subfamilies (Tristichoideae, Weddellinoideae, and Podostemoideae), which differ in the presence or absence of a spathella (a non-vascularized sac-like cover of the young flower), the number of stamens, pollen morphology, and the number of carpels and stigmas (Cook \& Rutishauser 2007, Koi et al. 2012, Rufhel et al. 2012). Unlike other aquatic angiosperms, vegetative propagation is not highly important and propagation through seeds is an important way to colonize new sites (Philbrick \& Novelo 1997, Philbrick et al. 2015).

Despite their great diversity, reproductive aspects of members of this family are known for only 29 species (Silva et al. 2014). To date, only sexual reproduction has been described (Philbrick \& Novelo 1997, Sobral-Leite et al. 2011). Autonomous self-pollination occurs in most species that have been studied (Philbrick 1984, Philbrick \& Novelo 1997, Khosla et al. 2000, Khosla et al. 2001, Okada \& Kato 2002, Philbrick \& Novelo 2006, Seghal et al. 2009, Seghal et al. 2010, Sobral-Leite et al. 2011, Khanduri et al. 2014) and is a common strategy for reproductive assurance.

Flowers of Podostemaceae have several morphological and biological traits that facilitate autonomous self-pollination. The modes of autonomous self-pollination in Podostemaceae are prior (Philbrick 1984, Khosla et al. 2000, Seghal et al. 2009), competing (Philbrick \& Novelo1997, Seghal et al. 2010, Khanduri et al. 2014), and delayed (Sobral-Leite et al. 2011). Some species possess true cleistogamy (Rutishaurser \& Grubert 1999, SobralLeite et al. 2011). Another strategy for reproductive assurance is wind pollination (Shivanna 2015), which has been described for some species of Podostemaceae, accompanied by self-pollination (Philbrick \& Novelo 1997, Seghal et al. 2010, Sobral-Leite et al. 2011).

To date, information on reproductive assurance strategies in Brasil is available for only two species of Podostemaceae (Philbrick et al. 2006, Sá-Haiad et al. 2010, Sobral-Leite et al. 2011). One of these species is Podostemum weddellianum (Tul.) C.T. Philbrick \& Novelo, a member of the Paleotropical clade of Podostemoideae, endemic to the Atlantic Forest (Philbrick and Novelo 2004, Ruhfel et al. 2011); studies of this species have focused only on herbarium and structural analyses, without field observations (Philbrick et al. 2006, Sá-Haiad et al. 2010). This species can occur sympatrically on rocky substrates in clear-water streams, together with Lophogyne lacunosa (Gardner) C.P.Bove \& C.T.Philbrick (Podostemoideae), a member of the Neotropical clade of Podostemoideae, also endemic to the Atlantic Forest (Philbrick and Novelo 2004, Ruhfel et al. 2011), and Tristicha trifaria (Bory ex Willd.) Spreng. (Tristichoideae), a cosmopolitan species (Bove et al. 2011; Kita \& Kato 2004). Although these species are not phylogenetically closely related (Ruhfel et al. 2011), they may share similar strategies of reproductive assurance because they are under the same selective pressure from their shared stressful habitat. Here, we investigated the anthesis dynamics, floral biology, and strategies for reproductive assurance (autonomous self-pollination and/or wind pollination) of Lophogyne lacunosa, Podostemum weddellianum, and Tristicha trifaria at the same location. We also describe the mating system of L. lacunosa, presenting the first report of apomixis in Podostemaceae.

\section{Material and methods}

Studied species and site - We carried out fieldwork on two populations of Lophogyne lacunosa, Podostemum weddellianum and Tristicha trifaria in the municipality of Macaé, Rio de Janeiro State, Brasil (site A, 22 $2^{\circ} 14^{\prime} 24.73^{\prime \prime} \mathrm{S}, 42^{\circ} 06^{\prime} 34.71^{\prime \prime} \mathrm{W}$ and site B, $22^{\circ} 14^{\prime} 14.55^{\prime}$ 'S, $42^{\circ} 06^{\prime} 34.71$ 'W) from April to October in 2012 and 2013. We considered each rock covered by plants as one unit (individual) because there is no clear limit between individuals that are interconnected by vegetative branches. Voucher specimens were deposited at R (Koschnitzke C. s/n R212744, Silva I.C. 76- R215899, and Silva I.C. 77-R215900, respectively) and collection data are available in the SpeciesLink Platform (http://splink. cria.org.br/).

Floral and fruit morphology studies - We randomly collected buds in pre-anthesis of three species $(n=10)$ and fixed them in $70 \%$ ethanol, to analyze their 
morphology. We dissected one anther per flower on a glass slide in $50 \%$ glycerin and observed it with an optical microscope (Axiostar Plus, Zeiss, Göttingen, Germany). We counted all the pollen grains on one stamen and obtained the number of pollen grains per flower by multiplying the number of grains on this stamen by the number of stamens in the flower. We counted the number of ovules in one ovary per flower in a Petri dish under a stereomicroscope. We analyzed fresh flowers ( $n=10$ of each species) to determine the color of their structures, and then fixed them in $70 \%$ ethanol to measure the flower structures with a digital caliper (Mitutoyo Corp, Kanogawa, Japan). We also took measurements of pedicels, andropodium, and filaments from newly opened flowers and flowers at 24 and $48 \mathrm{~h}(\mathrm{n}=10$ of each species at different floral stages) to detect elongation of these structures. We collected nearly ripe fruits of each species $(n=20)$ and analyzed them under a stereomicroscope, measured the ovary (length $\times$ width), and counted the number of seeds per fruit. We calculated the seed-ovule ratio for each species.

Floral biology - We marked buds of L. lacunosa $(\mathrm{n}=42), P$. weddellianum $(\mathrm{n}=41)$, and T. trifaria $(\mathrm{n}=38)$, monitoring them until flower senescence. We evaluated the process of floral opening, anthesis aspects, and floral longevity. We tested stigma receptivity from pre-anthesis buds $(\mathrm{n}=10)$ and flowers $(\mathrm{n}=10)$ with $10 \%$ hydrogen peroxide (Zeisler 1938). We estimated pollen viability and tested the presence of pollenkitt in buds $(\mathrm{n}=15)$ with $1 \%$ acetic carmine (Radford et al.1974).

Wind pollination - We constructed traps $(n=20)$ consisting of double-sided tape attached to glass slides, to measure airborne pollen (Bai et al. 2006). We placed these traps on rocks next to the plants (ca. $1 \mathrm{~m}$ ) and collected them after 24 hours. We compared the pollen adhered to traps with the prepared slides of pollen from L. lacunosa, P. weddellianum, and $T$. trifaria, under an optical microscope, and counted all pollen grains of each species adhered on the sticky surface (no stain techniques were used). The mean and standard deviation was calculated in Statistica 8 (StatSoft 2007).

Mating-system - We conducted the experiments to investigate the occurrence of apomixis only in $L$. lacunosa. The anthers of $P$. weddellianum open in the young bud stage; $T$. trifaria has very tiny flowers $(<4$ $\mathrm{mm})$ and few flowers were produced by individuals in the short period (ca. two months), which preclude manipulations; these conditions prevented matingsystem experiments in both species. The matingsystem treatment was done at site 1 , with donor flowers from site 2 . We bagged each unit (rocks about $75 \mathrm{~cm}$ in diameter; $\mathrm{n}=11$ ) in plastic bags to exclude biotic or abiotic sources of pollination, cut off all flowers to prevent contamination, and carried out experiments on newly opened flowers before the anthers had opened. In manual crosspollination, we emasculated newly opened flowers and transferred pollen from a donor flower (site 2) to receptor-flower stigmas (site 1). In the manual selfpollination, we transferred pollen grains to stigmas of the same flower. In the treatment of apomixis, we emasculated the flowers by removing the stigmas. To prevent cross-pollination in the bag, we removed all newly opened flowers after manual pollination. We marked flowers of unbagged individuals $(n=9)$ to compare with the treatment results. We measured fruits resulting from the control $(n=20)$ with a digital caliper and inspected the external texture and color of these fruits. Fruits of all treatments were dissected and the seeds counted. All statistical analyses were conducted with the program Statistica 8 (StatSoft $2007)$ and the significance level was $5 \%(\mathrm{p} \leq 0.05)$. We analyzed the fruit set using the chi-square test, differences in size between fruits with the t-test, and seed set with the Kruskal-Wallis test.

\section{Results}

Floral morphology and biology - Flowers are solitary, zygomorphic, greenish (Lophogyne lacunosa and Podostemum weddellianum), or vinaceous (Tristicha trifaria), with filiform (L. lacunosa and $P$. weddellianum) or oblong (T. trifaria) tepals. The androecium is comprised of one stamen in $T$. trifaria, two to four stamens in L. lacunosa, or two stamens on an andropodium in P.weddellianum. The gynoecium contains a bicarpellate (L. lacunosa and $P$. weddellianum) or tricarpellate (T. trifaria) ovary, and two lobate ( $P$. weddellianum), flabelliform ( $L$. lacunosa) or linear (T. trifaria) papillate stigmas. Flowers of these species produced 13,991 $\pm 2449,750$ \pm 34 , and $325 \pm 122$ pollen grains per flower; and 261 $\pm 70,102 \pm 51$, and $57 \pm 6$ ovules, respectively. Pollen viability was $78 \%$ (33 - 86\%) in L. lacunosa, 68\% (98 - 48\%) in P. weddellianum, and 89\% (64 - 92\%) in T. trifaria. Only pollen grains of $P$. weddellianum presented pollenkitt. All flowers of these three species Exhibited diurnal anthesis. 


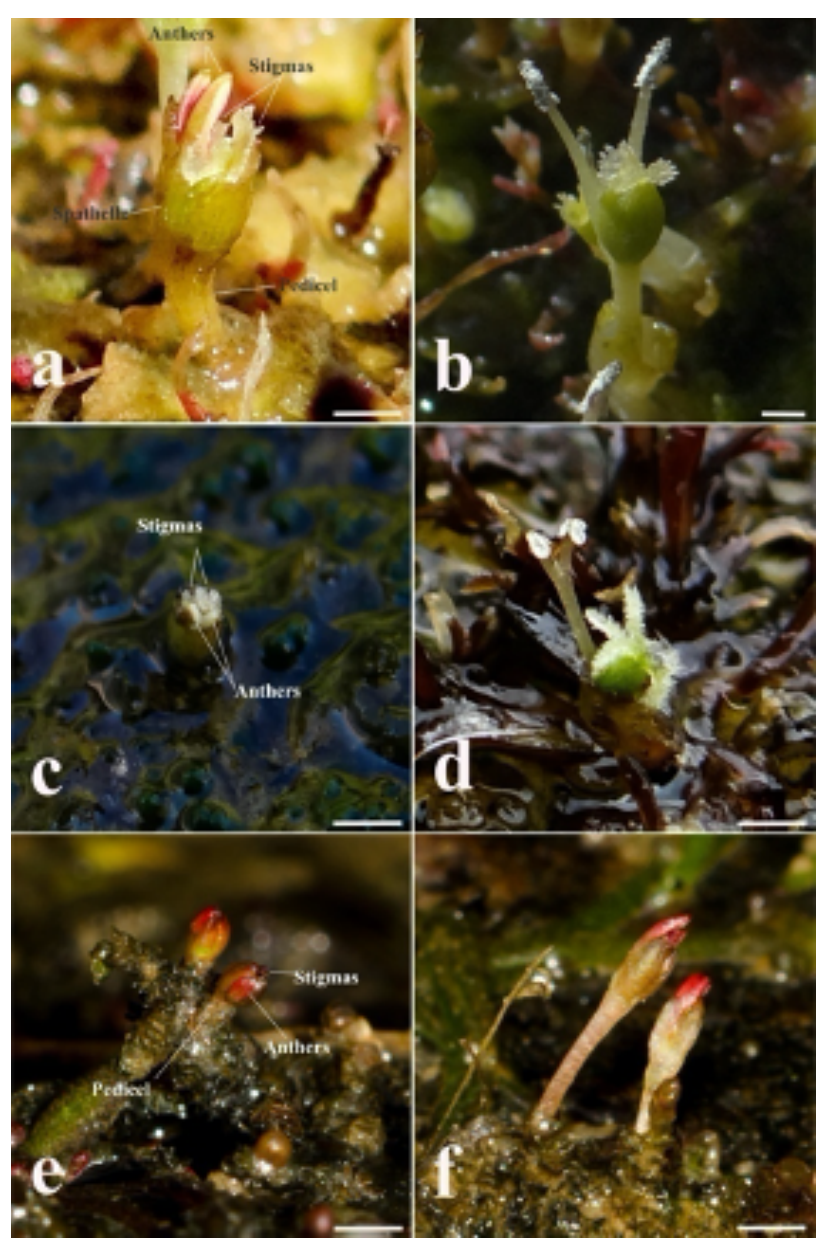

Figure 1. Flowers. a-b. Lophogyne lacunosa (Gardner) C.P. Bove $\&$ C.T. Philbrick. a. Newly opened flower with indehiscent anthers. b. Flower with dehiscent anthers above the stigma level. c-d. Podostemum weddellianum (Tul.) C.T. Philbrick \& Novelo. c. Newly opened flower with anthers opened close to the stigmas. d. Flower 48 hours after the beginning of the anthesis. e-f. Tristicha trifaria (Bory ex Willd.) Spreng. e. Newly opened flowers. f. Flowers 24 hours after the beginning of the anthesis. Note the anther at the same level as and close to the stigmas. Scale bars: a, $\mathrm{c}, \mathrm{d}, \mathrm{e}, \mathrm{f}=3 \mathrm{~mm} . \mathrm{b}=2 \mathrm{~mm}$.

Flowers of Lophogyne lacunosa (figure 1a) opened at two times, $86 \%$ in the morning (7:00-8:00h), and $14 \%$ in the afternoon (13:00-14:30h). During the first hours of the anthesis, the pedicel and filament elongated, projecting the flowers outside the spathella. After 7 hours, the pedicel and filament were still elongating (table 1) and the anthers became dehiscent. At this stage, the anthers were positioned above the stigmas (figure $1 \mathrm{~b}$ ) and the pollen fell directly on to them. In $17 \%$ of the observed flowers, the anthers were at the same level as the stigmas and touched them. Autonomous self-pollination occurred in flowers with or without an elongated filament. After 24 hours of anthesis, the anther turned light pink and still contained pollen. Between 72 and 96 hours, the anther color changed to brown, and the anthers twisted on their own axis, being completely spiral, and all pollen grains were released. At this stage, the stigmas were yellowish, well-distended, erect, and receptive. After 120 hours the anthers dropped and the stigmas turned brown.

Flowers of Podostemum weddellianum opened at two times, in the morning $81 \%(8: 00-9: 30 \mathrm{~h})$ and afternoon 19\% (13:00-14:30h). In newly opened flowers, the anthers and stigma were in very close proximity (figure 1c). During the first 24 hours, the pedicel and andropodium elongated (table 1 ) and the andropodium formed an angle of $45^{\circ}$ with the ovary in all observed flowers. After 48 hours of anthesis (figure 1d) the pedicel and andropodium were still elongating (table 1), increasing the angle to $90^{\circ}$ in all observed flowers. After 96 hours of anthesis, the anthers dropped and the stigmas turned yellowish. During the last 120 hours the stigmas turned brown and dry, dropping in some flowers.

Flowers of Tristicha trifaria opened only in the morning (8:00-10:00h), exposing only the stigma (figure 1e) by separation of the tepals. After 24 hours the pedicel and filament elongated (table 1) and the anthers became dehiscent. In $25 \%$ of the flowers, the anthers were at the same level of the stigmas (figure 1f), $60 \%$ had the anthers slightly exceeding the stigmas, and $15 \%$ had twisted filaments and anthers covering the stigmas. In all cases, the anthers and stigmas were very close to each other, and spontaneous self-pollination could occur when the anthers opened. After 120 hours of anthesis, the pedicel and filaments elongated (table 1) and the tepals, anthers, and stigmas turned brown.

Fruit morphology - Lophogyne lacunosa produced 0.78 seeded and 0.22 seedless fruits. Parthenocarpic (seedless) and non-parthenocarpic (seeded) fruits showed no significant differences in shape and size $(3.69 \pm 0.38 \times 1.5 \pm 0.13 \mathrm{~mm}$ and $3.80 \pm 0.43 \times 1.6$ $\pm 0.22 \mathrm{~mm}$, respectively). The fruits were ellipsoid, with ribs, and longitudinal dehiscence. Fruits (nonparthenocarpic) had $141 \pm 117$ seeds and a seed set of 0.54 . Podostemum weddellianum capsules (1.33 $\pm 0.2 \times 1.09 \pm 0.18 \mathrm{~mm}$ ) were orbicular, with a smooth surface, diagonal dehiscence, and the smaller valve caducous. All marked flowers (20) originated seeded fruits with $73 \pm 35$ seeds and a seed set of 0.74 . Tristicha trifaria capsules $(1.34 \pm 0.13 \times 0.78$ $\pm 0.1 \mathrm{~mm}$ ) were ellipsoid, with a smooth surface and longitudinal dehiscence. Only 0.20 of the marked 
flowers $(n=20)$ became fruits, with $15 \pm 2$ seeds and a seed set of 0.26 .

Wind pollination - We found (2) $64 \pm 48$ (200) pollen grains of Lophogyne lacunosa in one trap, totaling 466 grains, irregularly distributed on 18 traps (two traps were lost). We did not find pollen grains of $P$. weddellianum or T. trifaria on the traps.
Mating system of Lophogyne lacunosa - This species produced apomictic and parthenocarpic fruits (table 2). In the apomixis treatment, half of the resulting fruits were parthenocarpic, produced in cross- and self-pollination treatments as well as in the control. There were no significant differences between the treatment results.

Table 1. Pedicels, filament, and andropodium (only for Podostemum weddellianum (Tul.) C.T. Philbrick \& Novelo) elongation during the anthesis of Lophogyne lacunosa (Gardner) C.P. Bove \& C.T. Philbrick, Podostemum weddellianum, and Tristicha trifaria (Bory ex Willd.) Spreng. $(\mathrm{n}=10)$.

\begin{tabular}{lccc}
\hline Stages & Pedicel & Filament & Andropodium \\
\hline & Lophogyne lacunosa & & \\
Newly opened flower & $3.29 \pm 1.01$ & $2.53 \pm 0.55$ & - \\
Flower with close anther & $6.03 \pm 1.25$ & $3.1 \pm 0.61$ & - \\
Flower with open anther & $10.07 \pm 2$ & $3.77 \pm 1.1$ & \\
& Podostemum weddellianum & & \\
& $0.92 \pm 0.15$ & $0.36 \pm 0.1$ & $2.05 \pm 0.9$ \\
Newly opened flower & $1.33 \pm 0.26$ & $0.5 \pm 0.19$ & $2.42 \pm 0.61$ \\
Flower with 24 hours of anthesis & $1.76 \pm 0.82$ & $0.51 \pm 0.09$ & \\
Flower with 48 hours of anthesis & Tristicha trifaria & & - \\
& $0.83 \pm 0.10$ & $0.50 \pm 0.06$ & - \\
Newly opened flower & $1.54 \pm 0.47$ & $0.76 \pm 0.16$ & - \\
Flower with 24 hours of anthesis & $2.18 \pm 0.71$ & $1.22 \pm 0.24$ & \\
Flower with 48 hours of anthesis & & & \\
\hline
\end{tabular}

Table 2. Fruit set and parthenocarpic fruit set, with the total number of capsules produced and their percentages, formed in breeding-system treatments conducted on flowers of Lophogyne lacunosa (Gardner) C.P. Bove \& C.T. Philbrick. n: Number of flowers manipulated. Fruit set (\%): Number and percentage of fruits formed in each treatment. Parthenocarpic fruit set (\%): Number and percentage of parthenocarpic fruits formed in each treatment. Set of fruits with seeds $(\%)=$ set $(\%)$ : Number and percentage of fruits with seeds formed in each treatment. There were no significant differences between treatments $(\mathrm{p}<0.5)$.

\begin{tabular}{|c|c|c|c|c|c|c|}
\hline Treatment & $\mathrm{n}$ & $\begin{array}{c}\text { Fruit set } \\
(\%)\end{array}$ & $\begin{array}{c}\text { Parthenocarpic } \\
\text { fruit set }(\%)\end{array}$ & $\begin{array}{c}\text { Set of fruits } \\
\text { with seeds (\%) }\end{array}$ & $\begin{array}{l}\text { Mean number of seeds } \\
( \pm \text { standard deviation })\end{array}$ & $\begin{array}{c}\text { Range of number of } \\
\text { seeds }\end{array}$ \\
\hline Apomixis & 26 & $\begin{array}{c}16 \\
(62 \%)\end{array}$ & $\begin{array}{c}8 \\
(50 \%)\end{array}$ & $\begin{array}{c}8 \\
(50 \%)\end{array}$ & $\begin{array}{c}62 \\
( \pm 53.45)\end{array}$ & $1-133$ \\
\hline Cross-pollination & 42 & $\begin{array}{c}36 \\
(86 \%)\end{array}$ & $\begin{array}{c}12 \\
(33 \%)\end{array}$ & $\begin{array}{c}24 \\
(67 \%)\end{array}$ & $\begin{array}{c}20 \\
( \pm 30.05)\end{array}$ & $1-126$ \\
\hline Self-pollination & 22 & $\begin{array}{c}10 \\
(45 \%)\end{array}$ & $\begin{array}{c}3 \\
(30 \%)\end{array}$ & $\begin{array}{c}7 \\
(70 \%)\end{array}$ & $\begin{array}{c}16 \\
( \pm 14.70)\end{array}$ & $2-38$ \\
\hline Control & 20 & $\begin{array}{c}18 \\
(90 \%)\end{array}$ & $\begin{array}{c}4 \\
(22 \%)\end{array}$ & $\begin{array}{c}14 \\
(78 \%)\end{array}$ & $\begin{array}{c}141 \\
( \pm 117.87)\end{array}$ & $15-174$ \\
\hline
\end{tabular}




\section{Discussion}

The floral attributes of the species studied are: inconspicuous flowers with faint colors, well-exposed reproductive structures (as in most members of the family), and adaptations for autonomous selfpollination. This family possesses floral attributes that are distinct from the other members of the clusioid clade, a well-supported clade composed of Bonnetiaceae, Calophyllaceae, Clusiaceaes.s., Hypericaceae and Podostemaceae in the order Malpighiales (Kita \& Kato 2001; Ruhfel et al. 2011), offering only pollen as rewards for small groups of possible pollinators (Cook \& Rutishauser 2007). Other members of the clusiod clade have flowers with a wide diversity of adaptations for cross-pollination, offering nectar, pollen, and floral resin as rewards for several groups of pollinators (e.g. Amaral et al. 2017, Bartos et al. 2015, Sanfiorenzo et al. 2018, Versieux et al. 2014, Vlasáková et al. 2019). Podostemaceae is the only family of clusioids that occurs in rapids and waterfalls, an environment with high selective pressure, and unfavorable to visits of pollinators and crossing (e.g. Sobral-Leite et al. 2011). Therefore, as several attributes that can promote crossing are lacking, the Podostemaceae species need to invest in adaptations for reproductive assurance, such as autonomous selfpollination, to guarantee seed production.

Species of Podostemaceae have clear adaptations for autonomous self-pollination (Silva et al. 2014), such as: proximity between open anthers and receptive stigmas, overlap between male and female stages, and filament and/or andropodium elongation (Gupta \& Seghal 2009, Seghal et al. 2010, Khanduri et al. 2014, Krishman et al. 2019). All these aspects can be observed in the species studied here. Elongation of the filament and andropodium seems to be crucial to promote the self-pollination because the anthers and stigmas remain at the same level or the anthers are positioned above them. Interestingly, the andropodium elongation in $P$. weddellianum had a different function from the andropodium elongation in Zeylanidium maheshwarii C.J.Mathew \& Satheesh. In the former species, this mechanism moves the anthers away from the stigma, enabling cross-pollination after the prior autonomous self-pollination; in the latter species, the andropodium elongation places the anthers close to the stigma. Although these species have similar floral morphology, they possess different strategies of self- pollination (prior versus competing). The mechanisms to promote self-pollination in Podostemaceae are more complex than those described in Hypericum elodes (Hypericaceae, sister-group of Podostemaceae), because the pollen grains are deposited on the stigma just after the flower opens, by the proximity to the anthers without any movement or filament elongation (Carta et al. 2015). In Podostemaceae, the floral structures are well-exposed and in close proximity; these morphological features can facilitate the contact between receptive stigmas and anthers or autonomous deposition of pollen in all flower stages (inside the buds, during anthesis or in the final stages of anthesis). Until now, prior self-pollination has been reported only for members of the Paleotropical clade of Podostemoideae (an informal group): Griffithella hookeriana (Tul.) Warm. (Khosla et al. 2001), Hydrobryopsis sessilis (Willis) Engl. (Sehgal et al. 2009), and Podostemum ceratophyllum Michx. (Philbrick 1984). These authors described it as "preanthesis cleistogamy" according to the classification proposed by Lord (1982). However, in the most recent review on this subject, Culley \& Klooster (2007) defined this breeding system as self-pollinated flowers that remain permanently closed, and "preanthesis cleistogamy" was not considered a subtype of breeding system. Philbrick (1984) suggested that self-pollination inside the buds of Podostemum ceratophyllum may be a way to prevent the pollen from being wasted or washed away by the water. The tiny flowers of $P$. weddellianum may also remain close to the water surface and become submerged on rainy days. Probably the autonomous prior selfpollination in this species is to ensure the pollination and to avoid pollen waste; however, these hypotheses should be tested in the field, as previously suggested by Philbrick (1984). Floral attributes of these species contributed to this type of self-pollination, such as dehiscent anthers inside the buds, introrse dehiscence, early stigma maturation, and anthers at the same level as the stigmas inside the buds.

In aquatic plants, the occurrence of cleistogamy is sometimes related to the water level (Sculthorpe 1967). Evidence of this mating type has been reported for Mourera fluviatilis Tul. (Sobral-Leite et al. 2011), a species of the Neotropical clade of Podostemoideae with different floral morphology (showy inflorescences) and pollination system from the species studied here. We also found evidence of 
cleistogamy in $P$. weddellianum: fruits with an intact brown spathella, yellowish anthers without pollen grains, rigid brown ovaries with seeds, and brown stigmas. We observed during fieldwork that the water level rises rapidly on rainy days, submerging some $P$. weddellianum flowers. This could be considered a case of induced cleistogamy, in which non-opening flowers were affected by environmental factors (Culley \& Klooster 2007). Although L. lacunosa and T. trifaria grow in the same habitat, they did not show cleistogamy or autonomous prior self-pollination, because the anthers only dehisced after the flower opened.

Another strategy for reproductive assurance is wind pollination (Shivana 2015). This type of pollination requires some features related to the environment and plant traits that facilitate pollen dispersal and capture (Culley et al. 2002). Flowers of L. lacunosa have several of these features, related to the environment (open vegetation and proximity of individuals) and morphology (well-exposed stigmas and anthers, large stigmas in relation to flower size and powdery pollen grains). In contrast, flowers of $P$. weddellianum and T. trifaria have stigmas and anthers that are not well exposed (the flowers are very tiny and can be hidden by leaves) and have relatively few pollen grains (750 \pm 34 and $325 \pm 122$ per flower, respectively). In the case of $\mathrm{P}$. weddellianum, pollen grains are shed in dyads with pollenkitt. These attributes were not related to wind pollination and these species are probably not windpollinated. Wind pollination has been inferred from the pollination syndromes for Podostemaceae species (Cook \& Rutishauser 2007) but has been tested by mating-system experiments only for Marathrum foeniculaceum Bonpl. (cited as Marathrum rubrum Novelo \& C.T. Philbrick by Philbrick \& Novelo 1997) and Mourera fluviatilis (Sobral-Leite et al. 2011). These species lack the classical floral morphology described for species pollinated by wind-pollinated in Podostemaceae (Cook \& Rutishauser 2007), which increases the importance of tests to determine its occurrence in the family. Our experiments with pollen traps gave positive results and can be used for other Podostemaceae species to test the wind pollination.

Lophogyne lacunosa can produce seeds by apomixis as a facultative pathway because some individuals did not produce apomictic fruits and asexual and sexual reproduction may co-occur (autogamy and xenogamy). This is an interesting breeding strategy because genetic variability is increased through sexual reproduction and the number of seeds is increased through apomixis. Furthermore, apomixis may be the only alternative for seed production in case of pollination failure, including selfpollination (Koltunow 1993, Richards 2003), which may represent a strategy for reproductive assurance. Apomixis has been reported for some members of the Podostemaceae sister group, Hypericacaeae (Matzk et al. 2003), and in Clusiaceae, the sister group of Hypericaceae + Podostemaceae (Richards 1990, Ruhfel et al. 2011). Nonetheless, apomixis had not been observed in any other species of Podostemaceae, so the occurrence in L. lacunosa is the first report for this family.

Although Lophogyne lacunosa shows several strategies for reproductive assurance (autonomous competing self-pollination, apomixis, and wind pollination), it also produces parthenocarpic (seedless) fruits in natural conditions. Podostemum weddellianum, on the other hand, has prior autonomous self-pollination and this species produced the highest rate of fruit and seed set of the three species. Tristicha trifaria had the lowest fruit and seed set, and only competing autonomous self-pollination was observed. Most of the fruits of this species were lost; possibly because they were ripped off by rises in the water level or were consumed by herbivores (only their pedicels were left). Seeds of Podostemaceae have an important role in the maintenance of the population and/or establishment in new areas, because vegetative propagation may be less important (Philbrick \& Novelo 1995, 1997).

Waterfalls and rapids can be unfavorable environments for pollinators (Sobral-Leite et al. 2011), so strategies for reproductive assurance (autonomous self-pollination, wind pollination, and apomixis) may be important for these species. All the species studied here possess adaptations for autonomous self-pollination; however, each species has evolved a distinct strategy.

\section{Acknowledgments}

We thank Dr. C.T. Philbrick for valuable suggestions on the manuscript, MSc.Y.M. Canalli-Grego for contributions in fieldwork, Dr. M. Couriand and MSc. F.A. Rodrigues Júnior for Diptera identification, 
and Dr. Janet W. Reid for linguistic editing. This study was financed in part by the Coordenação de Aperfeiçoamento de Pessoal de Nível Superior Brasil (CAPES) - Finance Code 001 grant to I.C.S.B and $\mathrm{CNPq}$ (Conselho Nacional de Desenvolvimento Científico) grants, REFLORA 563534/2010-9 and Productivity Grant (307870/2014-6) to C.P.B.

\section{Literature cited}

Amaral, M.C.E.A., Bittrich, V., Endress, P.K. \& Stevens, P.F. 2017. The unique morphology of resin-producing multilocellate anthers and their evolution in Clusia (Clusiaceae). Botanical Journal of the Linnean Society 184: 79-93.

Bai, W.-N., Zeng Y.-F., Liao, W.J. \& Zhang, D.Y. 2006. Flowering phenology and wind-pollination efficacy of heterodichogamous Juglans mandshurica (Juglandaceae). Annals of Botany 98: 397-402.

Bartos, M., Tropek, R., Spitzer, L., Padysákova, E., Janista, P., Straka J., Tkoc, M. \& Janecek, S. 2015. Specialization of pollination systems of two co-flowering phenotypically generalized Hypericum species (Hypericaceae) in Cameroon. Arthropod-Plant Interactions 9: 241-252.

Bove, C.P., Philbrick, C.T. \& Costa, W.J.E.M. 2011. Taxonomy, distribution and emended description of the neotropical genus Lophogyne (Podostemaceae). Brittonia 63: 156-160.

Carta, A., Savio, L., Bedini, G., Peruzzi, L., Fisogni, A. \& Galloni, M. 2015. All in an afternoon: mixed breeding system in one-day lasting flowers of Hypericum elodes L. (Hypericaceae). Plant Biosystem 150(5):1001-1009.

Cook, C.D.K. \& Rutishauser, R. 2007. Podostemaceae. In: Kubitzki, K. (ed.). The Families and Genera of Vascular Plants. Berlin: Springer Verlag. 9: 304-344.

Culley, T.M. \& Klooster, M.R. 2007. The cleistogamy breeding system: A review of its frequency, evolution, and ecology in angiosperms. Botanical Reviews73: 1-30.

Eckert, C. G., Samis, K. E. \& Dart, S. 2006. Reproductive assurance and the evolution of uniparental reproduction in flowering plants. In: Harder, L. D. and Barrett, S. C. H. Ecology and Evolution of Flower. Oxford University Press, New York.

Gupta, C.K. \& Sehgal, A. 2009. Pollination biology of Indotristicha ramosissima (Podostemaceae: Tristichoideae). Aquatic Botany 91: 51-56.

Khanduri, P., Chaudhary, A., Uniyal, P.U. \& Tandon, R. 2014. Reproductive biology of Willisia arekaliana (Podostemaceae), a freshwater endemic species of India. Aquatic Botany 119: 57-65. DOI: 10.1016/j. aquabot.2014.06.008 0304-3770.
Khosla, C., Shivanna, K.R. \& Mohan Ram, H.Y. 2000. Reproductive biology of Polypleurum stylosum (Podostemaceae). Aquatic Botany 67: 143-154.

Khosla, C., Shivanna, K.R. \& Mohan Ram, H.Y. 2001. Cleistogamy in Griffithella hookeriana (Podostemaceae). South African Journal of Botany 67: 320-324.

Kita, Y. \& Kato, M. 2001. Infrafamilial phylogeny of the aquatic angiosperm Podostemaceae inferred from the nucleotide sequences of the matK gene. Plant Biology 3: $156-163$.

Kita, Y. \& Kato, M. 2004. Phylogenetic relationships between disjunctly occurring groups of Tristicha trifaria (Podostemaceae). Journal of Biogeography 31: 1605-1612.

Koi, S., Kita, Y., Hirayama, Y., Rutishauser, R., Huber, K.A. \& Kato, M. 2011. Molecular phylogenetic analysis of Podostemaceae: implications for taxonomy of major groups. Botanical. Journal of the Linnean Society 169: 461-492.

Koltunow, A.M. 1993. Apomixis: embryo sacs and embryos formed without meiosis or fertilization in ovules. Plant Cell 5: 1425-1437.

Krishnan, R., Khanduri, P. \& Tandon, R. 2019. Floral biology, pollination mechanism and embryo development in Zeylanidium maheshwarii (Podostemaceae). Vegetos 1: $1-10$.

Jäger-Zürn, I. 1997. Embryological and floral studies in Weddellina squamulosa Tul. (Podostemaceae, Tristichoideae). Aquatic Botany 57: 151-182.

Lord, E.M. 1982. Cleistogamy: A toll for the study of floral morphogenesis, functions and evolution. Botanical Review 47: 421-442.

Luna, R., Guzmán-Merodio, D., Núñez-Farfán, J., Philbrick, C.T., Collazo-Ortega, M. \& MárquezGuzmán, J. 2012. Cross compatibility between Marathrum rubrum and Marathrum schiedeanum (Podostemaceae), two closely related species of the Pacific Mexican Coast. Aquatic Botany 102: 1-7.

Matzk, F., Hammera, K. \& Schuber, I. 2003. Coevolution of apomixis and genome size within the genus Hypericum. Sexual Plant Reproduction 16: 51-58.

Okada, H. \& Kato, M. 2002. Pollination systems inferred from pollen-ovule ratios of some species of Podostemaceae. Acta Phytotaxonomica et Geobotanica 53: 51-61.

Philbrick, C.T. 1984. Aspects of floral biology, breeding system, seed and seedling biology in Podostemum ceratophyllum (Podostemaceae). Systematic Botany 9: 166-174.

Philbrick, C.T., Bove, C.P. \& Stevens, H.I. 2010. Endemism in neotropical Podostemaceae. Annals of the Missouri Botanical Garden 97: 425-456. 
Philbrick C.T. \& Les, D.L., 1996. Evolution of aquatic angiosperm reproductive systems. BioScience 46: 813-826.

Philbrick, C.T. \& Novelo, A.R. 1993. A fascinating family of aquatic flowering plants. Aquaphyte 13: 1-7.

Philbrick, C.T. \& Novelo, A.R. 1995. New World Podostemaceae: ecological and evolutionary enigmas. Brittonia 47: 210-222.

Philbrick, C.T. \& Novelo, A.R. 1997. Ovule number, seed number and seed size in Mexican and North American species of Podostemaceae. Aquatic Botany 57: 183-200.

Philbrick, C.T. \& Novelo, A.R. 1998. Flowering phenology, pollen flow, and seed production in Marathrum rubrum (Podostemaceae). Aquatic Botany 62: 199-206.

Philbrick, C.T. \& Novelo, A.R. 2004. Monograph of Podostemum (Podostemaceae). Systematic Botany 70: 1-106.

Philbrick, C.T., Philbrick, P. K.B. \& Lester, B.M. 2015. Root fragments as dispersal propagules in the aquatic angiosperm Podostemum ceratophyllum Michx. (Horn leaf Riverweed, Podostemaceae). Northeastern Naturalist 22: 643-647.

Radford, A.E., Dickson, W.C., Massey, J.R. \& Bell, C.R. 1974. Vascular Plant Systematics. Harper and Row, New York.

Richards, A.J.1990. Studies in Garcinia and dioecious tropical forest trees: agamospermy. Botanical Journal of the Linnean Society 103: 233-250.

Richards, A.J. 2003. Apomixis in flowering plants: an overview. Philosophical Transactions of the Royal Society of London Biological Sciences 358: 1085-1093.

Ruhfel, B.R., Bittrich, V., Bove, C.P., Gustafsson, M.H.G., Philbrick, C.T., Rutishauser, R., Zhenxiang, X.I. \& Davis, C.C. 2011. Phylogeny of clusoid clade (Malpighiales): evidence from plastids, mitochondrial genomes. American Journal of Botany 98: 306-325.

Sá-Haiad, B., Torres, C.A., Abreu, V.H.R., Gonçalves, M.R., Mendonça, C.B.F., Santiago-Fernandes, L.D.R., Bove, C.P. \& Gonçalves-Esteves, V. 2010. Floral structure and palynology of Podostemum weddellianum (Podostemaceae: Malpighiales). Plant Systematics and Evolution 290: 141-149.
Sanfiorenzo, A., Finegan, B. \&Walts, L.P. 2018. Potential pollinators of understory populations of Symphonia globelifera in the Neotropics. Journal of Pollination Ecology 22: 1-10.

Sculthorpe, C.D. 1967. The Biology of Aquatic Vascular Plants. Edward Arnold Ltd., London.

Sehgal, A., Sethi, M. \& Mohan Ram, H.Y. 2009. Development of the floral shoot and pre-anthesis cleistogamy in Hydrobryopsis sessilis. Botanical Journal of the Linnean Society 159: 222-236.

Shivanna, K.R. 2015. Reproductive assurance through autogamous self-pollination across diverse sexual and breeding systems. Current Science 109: 1255-1263.

Silva, I.C., Bove, C.P. \& Koschnitzke, C. 2014. Plantas de corredeiras: reprodução e conservação de Podostemaceae. Natureza online 13: 6-11.

Sobral-Leite, M., Siqueira Filho, J.A., Erbar, C. \& Machado, I.C. 2011. Anthecology and reproductive system of Mourera fluviatilis (Podostemeaceae): pollination by bees and xenogamy in a predominantly anemophilous and autogamous family. Aquatic Botany 95: 77-87.

StatSoft, Inc. 2007. STATISTICA (data analysis software system), version 8.0. www.statsoft.com.

Tippery, N.P., Philbrick, C.T., Bove, C.P. \& Les, D.H. 2011. Systematics and phylogeny of neotropical Podostemaceae. Systematic Botany 36: 105-118.

Vlasáková, B., Pinc, J., Jůna, F., \& Kotyková Varadínová, Z. 2019. Pollination efficiency of cockroaches and other floral visitors of Clusia blattophila. Plant Biology 21:753-761.

Versieux, L.M., Acosta, A.L., Jordão, A.L., Zidko, A. \& Maia, U.M. 2014. Floral biology, morphology and ecological niche modelling of Caraipa grandifolia (Calophyllaceae), an important amazonian floodplain tree. Boletim Museu Paraense Emílio Goeldi. Ciência Natural 9: 465-479.

Zeisler, M. 1938. Über die Abgrenzung der eigentlichen Narben-flächemit der Hilfe von Reaktionen. Beiheftezum Botanischen Zentralblatt 58: 308-318. 